\section{BA Institute of \\ YK Business Administration \\ 六下 \\ Karachi \\ Leadership and Ideas for Tomorrow}

Business Review

Volume 4 Issue 2 July-December 2009

$1-7-2009$

\title{
Factors affecting business success of Small and Medium Enterprises (SMEs) in Bangladesh
}

\author{
Muhammad Aminul Islam \\ University Sains Malaysia, Penang, Malaysia \\ Ejaz Ahmad Mian \\ University Sains Malaysia, Penang, Malaysia \\ Muhammad Hasmat Ali \\ University Sains Malaysia, Penang, Malaysia
}

Follow this and additional works at: https://ir.iba.edu.pk/businessreview

Part of the Entrepreneurial and Small Business Operations Commons, and the Growth and Development Commons

\section{(c) (1)}

This work is licensed under a Creative Commons Attribution 4.0 International License.

\section{Recommended Citation}

Islam, M. A., Mian, E. A., \& Ali, M. H. (2009). Factors affecting business success of Small and Medium Enterprises (SMEs) in Bangladesh. Business Review, 4(2), 123-138. Retrieved from https://doi.org/ 10.54784/1990-6587.1336

This article is brought to you by iRepository for open access under the Creative Commons Attribution 4.0 License and is available at https://ir.iba.edu.pk/businessreview/vol4/iss2/10. For more information, please contact irepository@iba.edu.pk. 


\title{
Case Study
}

\section{Factors Affecting Business Success of Small and Medium Enterprises $\left(\mathrm{SME}_{\mathbf{S}}\right)$ in Bangladesh}

\author{
Muhammad Aminul Islam \\ University Sains Malaysia, Penang, Malaysia \\ Ejaz Ahmad Mian \\ University Sains Malaysia, Penang, Malaysia \\ Muhammad Hasmat Ali \\ University Sains Malaysia, Penang, Malaysia
}

\begin{abstract}
This study examines determinants for small business success in Bangla Desh. These include: characteristic of SMEs, their management and know-how, products and services, style of doing business, financial and other resources and external environment. Such study has not been conducted before in the context of Bangla Desh. Findings of the study are useful for entrepreneurs and policy makers. Study is based on survey methodology through a questionnaire administered on the employees of small firms. Data is analyzed using SPSS. Six hypotheses are proposed and tested. Most significant factors affecting business success of SMEs in Bangladesh were found to be products and services, the way of doing business, management know-how and, external environment. This study has implications for entrepreneurs and policy makers.
\end{abstract}

Key Words: Business Success, SMEs, Bangladesh

\subsection{INTRODUCTION}

Research into small and medium sized enterprises (SMEs) has grown strikingly during the last decade. This intense attention in the backdrop of the failure of various structural and trade policy reforms to stimulate any significant response from the private sector is remarkable, and seems to suggest that liberalization measures must be supplemented by proactive policies to attain the desired goal (Bhattacharya, 2002). A huge majority of firms worldwide are SMEs, and they play a significant role in the economy. There is a broad consensus that a vibrant SME sector is one of the principal driving forces in the development of a market economy (Kazmil and Farooquie, 2000). Small businesses can enable rapid industrialization and accelerated economic growth. Recent literature from all parts of the world suggests importance of SMEs in the overall performance of economy, including USA (Audretsch, 1998), Japan (Urata and Kawai, 1998), East Asia (Berry and Mazumdar, 1991), and Africa (Morisette et al., 1996). SMEs play an important role in economic structure and performance (Berry, 1997). In spite of the recognition of their importance, performance of SMEs has always fallen short of expectations (Arinaitwe, 2006). One of the reasons is that they cannot compete in technology with medium or large scale business (Rana et al., 2003).

SMEs stimulate private ownership and entrepreneurial skills, are flexible and can adapt quickly to changing market demand and supply situations, generate employment, help diversify economic activity, and make a significant contribution to exports and trade. Even in the developed market economies SMEs account for a large share in output and employment 
(UNECE, 2003). Bangladesh has thus far failed to maximize the benefits derived from the SME sector, which promises and needs to play a pivotal role in promoting and sustaining the industrial as well as overall economic growth (Ahmed M. U., 2003). The failure can be attributed to various reforms and trade liberalization measures that have squeezed the sphere of Government's activity in business. Consequently, the private sector has to lead the economy in a dynamic growth path. Most of the previous studies dealing with the conditions of successful business have focused on large companies rather than SMEs (i.e., Ghosh and Kwan, 1996; Kauranen, 1996 and Pelham, 2000). However, changes in the environment cause more uncertainty in SMEs than in large companies. Their resources for acquiring information about the market and changing the course of the enterprise are more limited. The response to environmental changes is different in SMEs than in large companies. Large firms may even exit from one of its business areas, but this is not usually possible in a singlebusiness firm. The options for responding are limited by the firms' resources and strategic choices as well as by the opportunities offered by the industry and location. Those ways may also differ between the development stages of the firm. SMEs have long been believed to be important in supporting economics development within a country (Mazzarol, Volery, Doss, \& Thein, 1999). One of the important roles of SMEs in this context includes poverty alleviation through job creation. Thai SMEs are increasingly seen as creator of new jobs (Swierczek \& Ha, 2003) and Vietnamese SMEs employ 64\% of industrial workforce. Therefore findings on SMEs in Bangladesh will help the policymakers in Bangladesh particularly and will also help other developing countries to formulate strategies to strengthen and stabilize SMEs operations in respective countries.

\subsection{LITERATURE REVIEW}

The word enterprise has been used in a range of contexts and meanings (Bridge, O’Neill \& Cromie 2003). Salminen (2000) describes an enterprise as a controlled system consisting of a detector, a selector and an effector. The detector is the function by which a system acquires information about its environment, which is then used as the basis of the selection of a behavioral response by the selector. Finally, the behavior is executed by the effector. The measurement system of an enterprise gathers information about the changes in both the environment and the performance of the enterprise. This information is then used together with the values and the preferences of the enterprise and its management to produce decisions about the required actions. As a result, the outputs of the enterprise - the products, the services, the operational performance and the financial performance - are changed.

Firm performance refers to the firm's success in the market, which may have different outcomes. Firm performance is a focal phenomenon in business studies. However, it is also a complex and multidimensional phenomenon. Performance can be characterized as the firm's ability to create acceptable outcomes and actions.

Success, in general, relates to the achievement of goals and objectives in whatever sector of human life. In business life, success is a key term in the field of management, although it is not always explicitly stated. Success and failure can be interpreted as measures of good or indifferent management. In business studies, the concept of success is often used to refer to a firm's financial performance. However, there is no universally accepted definition of success, and business success has been interpreted in many ways (Foley \& Green 1989). 
There are at least two important dimensions of success: 1) financial vs. other success; and 2) short- vs. long-term success. Hence, success can have different forms, e.g. survival, profit; return on investment, sales growth, number of employed, happiness, reputation, and so on. In other words, success can be seen to have different meanings by different people. In spite of these differences, people generally seem to have a similar idea of the phenomenon, i.e. of what kind of business is successful.

\subsection{Contribution of SMEs in the National Economy of Bangladesh}

Any precise quantitative estimate of the importance of SMEs in Bangladesh economy is precluded by non-availability of comprehensive statistical information about these industries at the national level. BSCIC estimates suggest that there are currently 55,916 small industries and 511,612 cottage industries excluding handlooms. Including handlooms, the number of cottage units shoots up to 600,000 units indicating numerical abundance of small and cottage industries (SCIs) in Bangladesh. The most recent private sector survey estimates the contribution of the micro, small, and medium enterprises (MSMEs) is 20-25\% of GDP. Quoting informal Planning Commission estimates, the SEDF puts the number of medium enterprises (undefined) to be around 20,000 and that of SCIs to be between 100,000 to 150,000 . This wide variation in the BSCIC and Planning Commission estimates of the number of SMEs might be due to at least two reasons: (a) different definitions of SMEs and (b) different coverage of SME families. There is an urgent need for adopting and using a uniform set of definitions for SMEs by all government agencies to help formulation of pro-active SME promotion policies. Regardless of the correct magnitude, SMEs undoubtedly play a very important role in the economy of Bangladesh in terms of output, employment, and private sector activities (Ahmed, 2003). They are quite predominant in the industrial structure of Bangladesh comprising over $90 \%$ of all industrial units. Together, the various categories of SMEs are reported to contribute between $80-85 \%$ of industrial employment and $23 \%$ of total civilian employment (SEDF, 2003). However, serious controversies surround their relative contribution to Bangladesh's industrial output due to paucity of reliable information and different methods used to estimate the magnitude. The most commonly quoted figure by different sources (ADB, World Bank, Planning Commission and BIDS) relating to value added contributions of the SMEs is seen to vary between $45-50 \%$ of the total manufacturing value added.

A significant proportion of SME activities may be in the informal sector, for which there is no dependable information. Besides, the survey estimates SME contribution based on an approach that requires the use of data on profits earned by enterprises. However, it is very difficult to gather and measure profits of establishments. Therefore, the aforementioned contribution of SMEs may be underestimated. Further discussions on the role of SMEs in Bangladesh's economy can be found in (Ahmed, M.U., (2003). The robustness of SME contributions to employment generation is a common phenomenon in most developing countries in that the magnitude varies between $70 \%$ to $95 \%$ in Africa and $40 \%$ to $70 \%$ in the countries of the Asia-Pacific region (Ahmed, M.U., 1999). While SMEs are characteristically highly diverse and heterogeneous, their traditional dominance is in a few industrial subsectors such as food, textiles and light engineering and wood, cane and bamboo products. According to SEDF sources quoted from ADB (2003), food and textile units including garments account for over $60 \%$ of the registered SMEs. Various recent studies (Ahmed, M.U. 2001, ADB 2001, USAID 2001) show that SMEs have undergone significant structural 
changes in terms of product composition, degree of capitalization and market penetration in order to adjust to changes in technology, market demand and market access brought by globalization and market liberalization.

\subsection{Structural Transformation and growth of SMEs in Bangladesh}

In terms of number of establishment, the SME sub-sector has exhibited notable dynamism. Table 1 presents the trend of SME sector growth. Available evidence (Ahmed M.U. et. al., 1992) suggests that $60 \%$ of new industrial enterprises during 1980 s were SMEs.

Table 1: Growth of SSIs sector (Excluding Handlooms) in Bangladesh

\begin{tabular}{llllll} 
Year & \multicolumn{2}{l}{ No. of Units } & \multicolumn{2}{l}{ Employment } & Value Added (Tk.) \\
& Small & Cottage & Small & Cottage & Small and Cottage \\
& & & & & Combined \\
\hline 1981 & 24,590 & 321,743 & 322,110 & 855,200 & 17,987 \\
1991 & 38,294 & 405,476 & 523,472 & $1,331.032$ & 21,154 \\
2001 & 55,916 & 511,621 & 808,959 & $1,166,724$ & 29,323 \\
Average Annual & & & & & \\
Growth Rate & $6.4 \%$ & $3.0 \%$ & $7.6 \%$ & $4.7 \%$ & $3.2 \%$ \\
\hline
\end{tabular}

Source: Ahmad, M. U., 2001.

Growth in SME employment seems to have been even better during the same period. The dismal performance in value added growth is explained by the weak and faulty database used by the Bangladesh Bureau of Statistics (BBS) to estimate the parameters (Bakht 2001). Indeed, when revised estimates of value addition in the SMEs are made using the new system of national accounts, the annual compound rate of growth of value added by the SME sector not only shots up to $7.7 \%$ per annum during 1989/90 and 1994/95, it exceeds that of the large-scale industries during most of the 1990s.

Broadly four industry categories (food and allied products, textiles and apparels, and engineering and fabricated metal products) currently dominate the SME sector in Bangladesh. In recent years, other industries which have grown in importance in the SME sector are light engineering, readymade garments, printing and publishing, wood and wood products, plastic products, electrical goods, electronics, artificial jewelry, wooden and steel furniture, television and radio assembling and soaps and detergents. The growth in new sectors is reflective of a structural change taking place in the SME sector from traditional to relatively modern product categories, perhaps with higher capitalization and use of better production techniques. Summarizing the findings of various major studies the SEDF lists the following important positive changes taking place in the situation of the SMEs in Bangladesh: SMEs have diversified their activities, entry and exit into the sector has become easier, the RMG industry has contributed significantly to SME development by providing them with orders for accessories and packaging materials, the development of the footwear industry has increased subcontracts to SMEs, small-scale entrepreneurship has grown significantly in agro-processing in general and in poultry in particular. 


\subsection{Factors Affecting Business Success in SMEs}

There is considerable variation in the criteria for success used in previous studies. Empirical studies of factors affecting SME success can be roughly divided into two groups according to whether they focus on a quite limited set of variables or try to capture more holistic profiles of successful SMEs. Previous empirical research has used both surveys and case studies. There are also some compilations of the results of previous studies of the factors contributing to firm success. For instance, Storey (2000) has compiled the results of previous studies focused on the birth, growth and death of small firms, on the basis of which he presents some normative "dos and don'ts" lessons for small firms.

The following recent studies based on surveys have dealt with the factors affecting SME success. Nurul Indarti and Marja Langenberg (2005) identified key components to be important in analyzing the business success of SMEs which includes the characteristics of the entrepreneurs; the characteristics of the SMEs; and the contextual elements of SME development. Westhead (1995) studied factors influencing the survival of 227 high-technology small firms. Ghosh and Kwan (1996) made a cross national inter-sectoral study of the key success factors of 152 SMEs in Singapore and 164 SMEs in Australia. Kauranen (1996) carried out a follow-up study of 37 new manufacturing firms in Finland and studied the determinants of the future success of the firm in the short term and in the long term. Yusuf (1995) explored critical success factors for small firms in several industry sectors based on the perceptions of 220 South Pacific entrepreneurs. Wijewardena and Cooray (1996) explored the importance of a set of success factors by studying a sample of 300 small manufacturing firms in Japan. Gadenne (1998) investigated the effect of various management practices on small firm performance by studying 369 small businesses in the retail, service, and manufacturing industry in Australia. Bracker and Pearson (1986) studied planning and financial performance of small mature firms in the dry cleaning business. Baker et al. (1993) studied planning in successful high-growth small firms. Pelham (2000) explored the relationship between market orientation and the performance of manufacturing SMEs in eight industry sectors.

Based on the findings of earlier research, the factors affecting SME business success were classified into the following categories: (1) an entrepreneur Characteristics (Kristiansen, Furuholt, \& Wahid, 2003; and Rutherford \& Oswald, 2000), (2) characteristic of SME (Kristiansen, Furuholt, \& Wahid; 2003), (3) management and know-how (Swierczek \& Ha, 2003), (4) products and services (Wiklund 1998; and Hitt \& Ireland 2000). (5) Customers and markets (William, James, \& Susan; 2005), (6) the way of doing business and cooperation (Hitt \& Ireland 2000; and Jarillo 1988). (7) Resources and finance (Swierczek \& Ha, 2003; and Kristiansen, Furuholt \& Wahid, 2003). (8) strategy (McMahon, 2001), (9) external environment (Huggins, 2000; and Nurul Indarti \& Marja Langenberg, 2005); and (10) internet (Henriette Hesselmann, Comcare, and Peter Bangs; 2002). However only 6 factors namely Characteristics of SMEs, Management and know-how, Products and Services, The Way of Doing Business and Cooperation, Resources and Finance and External Environment were considered for the theoretical framework of this study based on suitability with Bangladeshi context. Therefore, Business success is the dependent variable and independent variables are: characteristic of entrepreneur and SMEs, management and know-how, products and services, the way of doing business and cooperation, resources and finance, and external environment. 


\subsection{RESEARCH METHODOLOGY}

A sample of 300 employees from SMEs located in the Dhaka, Narayangonj, Khulna and Chittagong were chosen for the purpose of this study. This geographical area has been chosen as they represent a large number of SMEs in Bangladesh. The population frame was drawn from the list obtained from the Bangladesh Small and Cottage Industries Corporation (BSCIC). Respondents represent the four broad categories of SMEs namely; food and allied products, textiles and apparels, engineering, and fabricated metal products. Each SME represented with one respondent only. The questionnaires were distributed based on the sample ratio scale down statistics to ensure it is able to represent the sample population obtained from the BSCIC. Data collection was accomplished by mail and personal delivery. The sampled companies were contacted in advance by telephone. The population of the study consisted of front-line employees and middle management levels of SMEs in those areas mentioned earlier. A self-designed questionnaire was used to gather the research data. The questionnaire consisted of three parts. The first part comprised of demographic, characteristic, and profile information of the respondents. The respondents were asked to rank statements on contextual condition related to each success factor faced by the respondents in the second part. This part consisted of 45 questions which were intended to measure factors of business success, using 5-point Likert scale anchored by strongly agree to strongly disagree. The factors were characteristic of SMEs, management and know-how, products and services, the way of doing business and cooperation, resources and finance, strategy, management know how; and external environment. In the third part, the respondents were asked to score the importance of perceived of business success. Five-point Likert scale anchored by strongly agree and strongly disagree were applied to measure the perceived success. A total 300 sets of questionnaires were distributed among managers of SMEs, only 95 participants were responded. A total of 95 were received and 89 were selected to ensure sampling match the ratio of percentage of working gender, age group, and level of management they are involved.

From the above theoretical framework, the following hypotheses were derived:

H1 There is a positive relationship between firm characteristics and business success in SMEs.

H2 There is a positive relationship between management know-how and business success in SMEs.

H3 There is a positive relationship between products \& services and business success in SMEs.

H4 There is a positive relationship between the way of doing business, cooperation and business success in SMEs.

H5 There is a positive relationship between resources \& finance and business success in SMEs.

H6 There is a positive relationship between external environment and business success in SMEs.

\subsection{SURVEY RESULTS}

A total 300 sets of questionnaires were distributed to selected respondents, only 95 questionnaires were collected back; the response rate is $31.46 \%$ (i.e. 95/302). 
However only 89 questionnaires were used for analysis, three questionnaires was rejected due to the respondents were not from the management level.

Descriptive analysis shows that out of 89 respondents, there were more male than female respondents. The results show that $82 \%$ of the respondents are male and the remaining $18 \%$ are female. Table 2 presents the demographic characteristics of respondents.

\begin{tabular}{|c|c|c|c|}
\hline Variables & Categories & Frequency & Percentage $(\%)$ \\
\hline \multirow[t]{2}{*}{ Gender } & Male & 73 & 82 \\
\hline & Female & 16 & 18 \\
\hline \multirow[t]{5}{*}{ Age } & $<21$ & 0 & 0 \\
\hline & $21-30$ & 21 & 23.6 \\
\hline & $31-40$ & 44 & 49.4 \\
\hline & $41-50$ & 21 & 23.6 \\
\hline & Above 50 years old & 3 & 3.4 \\
\hline \multirow[t]{6}{*}{ Education Level } & Primary School & 0 & 0 \\
\hline & Secondary School & 5 & 5.6 \\
\hline & Certificate/Diploma & 20 & 22.5 \\
\hline & Bachelor's Degree & 40 & 44.9 \\
\hline & Master's Degree & 24 & 27 \\
\hline & $\mathrm{PhD} / \mathrm{DBA}$ & 0 & 0 \\
\hline \multirow[t]{5}{*}{ Working Experience } & $<2$ years & 2 & 2.2 \\
\hline & $2-5$ years & 10 & 11.2 \\
\hline & $6-10$ years & 27 & 32.6 \\
\hline & $10-20$ years & 33 & 37.1 \\
\hline & $>20$ years & 15 & 16.9 \\
\hline \multicolumn{4}{|l|}{ Duration of } \\
\hline \multirow[t]{5}{*}{ Organization Operate } & $<5$ years & 18 & 20.2 \\
\hline & $5-10$ years & 21 & 23.6 \\
\hline & $10-15$ years & 17 & 19.1 \\
\hline & $15-20$ years & 7 & 7.9 \\
\hline & $>20$ years & 26 & 29.2 \\
\hline \multirow[t]{4}{*}{ Sectors } & Food and Allied Products & 19 & 21.3 \\
\hline & Textiles and Apparels & 29 & 32.6 \\
\hline & Engineering & 24 & 26.9 \\
\hline & Fabricated metal Products & 17 & 19.1 \\
\hline
\end{tabular}

Table 2: Demographic Characteristics of Respondents

The majority of respondents, a total of $44(49.4 \%)$ were aged between 31 to 40 years old, $23.6 \%$ each (21 each) were aged between 21 to 30 and 41 to 50 years old, $3.4 \%$ (3) were above 50 years old, and $0 \%$ of respondents were from age less than 20 years old. There are zero respondent from Primary School, 5 (5.6\%) were from Secondary School, 20 $(22.5 \%)$ were from Certificate/Diploma, 40 (44.9\%) were from Bachelor's Degree, 24 (27\%) were from Master's Degree, and no respondent from $\mathrm{PhD} / \mathrm{DBA}$. Two respondents having working experience less than 2 years $(2.2 \%), 10(11.2 \%)$ respondents between 2 to 5 years, 
$29(32.6 \%)$ respondents were between 6 to 10 years, $33(37.1 \%)$ respondents were between 10 to 20 years, and $15(16.9 \%)$ respondents were more than 20 years. On the other hand for the Duration of Organization Operated, $18(20.2 \%)$ were less than 5 years, $21(23.6 \%)$ were between 5 to 10 years, $17(19.1 \%)$ were between 10 to 15 years, $7(7.9 \%)$ were between 15 to 20 years, and $26(29.2 \%)$ were more than 20 years. Finally textiles and apparels have the highest number of respondents (32.6\%), followed by engineering $(26.9 \%)$.

Reliability analysis was used to measure both consistency and internal stability of data. Table 3 presents the results of reliability analysis.

Variables

SMEs Characteristic

Management and Know-How

Products and Services

The Way of doing Business

\& Cooperation

Resources and Finance

External Environment

Perceived of Business Success
Number of Items

Items Dropped
Cronbach's Alpha

0.864

0.821

0.896

0.802

0.797

0.769

0.911

\section{Table 3: Results of Reliability Analysis}

The Cronbach's Alpha measuring the inter-item consistency and reliability measure the coefficient that reflects how well items in a set are positively correlated to one another. Cronbach's Alpha that are less than 0.6 are generally considered to be poor, those in the 0.7 range to be acceptable, and those over 0.8 to be good; the closer the reliability coefficient gets to 1.0, the better. Cronbach's Alpha for six independent variables and the dependent variable were above .70 . Therefore data that were collected for this research were considered to be internally stable and consistent.

\subsection{Factors Affecting Business Success of SMEs}

Multiple Regression Analysis was used to determine whether the six independent variables, which are SMEs characteristic, management and know-how, products and services, the way of doing business and cooperation, resources and finance, management know how; and external environment, have any significant effect toward Business Success of SMEs in Bangladesh. The results are shown in Table 4.

The findings of the study revealed that products and Services, management knowhow, the way of doing Business \& Cooperation, and External Environment have significant positive effect on the Business Success of SMEs in Bangladesh. Characteristics of SMEs, and, resources and finance were found to have no significant effect on the Business Success of SMEs in Bangladesh. 


\begin{tabular}{|c|c|c|c|}
\hline Factors & Beta & T-Ratio & Sig. $t$ \\
\hline SMEs Characteristic & 0.046 & 0.312 & 0.756 \\
\hline Management and Know-How & 0.218 & 1.561 & 0.048 \\
\hline Products and Services & 0.265 & 1.955 & 0.033 \\
\hline The Way of doing Business \& Cooperation & 0.227 & 1.630 & 0.039 \\
\hline Resources and Finance & 0.051 & 0.559 & 0.578 \\
\hline External Environment & 0.288 & 2.265 & 0.019 \\
\hline \multicolumn{4}{|c|}{$\begin{array}{l}\mathrm{R} \text { square }=0.523 \\
\text { urbin-Watson }=1.545 \\
\mathrm{~F}=15.561 \\
\text { Sig. } \mathrm{F}=0.000 \\
\text { ndition Index }=41.042\end{array}$} \\
\hline
\end{tabular}

\section{Table 4: Results of Regression Analysis on the Business Success of SMEs}

The overall results of the regression analysis shows that this model is well constructed and it is well represented as reflected in the variables selected. Table 4, the summary table on regression analysis indicated that the R-square is 52.3 percent. This means that the seven variables which include SMEs characteristic, management and know-how, products and services, the way of doing business and cooperation, resources and finance, and external environment can explain 52.3 percent variations in the business success of SMEs in Bangladesh.

The Durbin-Watson statistic shows that the serial correlation of residuals is 1.545 , the value falls within the acceptance range (1.5 to 2.5$)$. This means that there is no auto correlation problem in the data. The Condition Index, Variance Inflation Factors (VIF) and tolerance all fall within the acceptance range (Condition index $=30.083, \mathrm{VIF}=1-10$, tolerance $=0.1-1.0)$. This means that there is no multi-collinearity problem in the regression model used for this study. The histogram indicates that data used in this study is normally distributed and $\mathrm{F}$-value is found to be significant at $1 \%$ significance level (sig. $\mathrm{F}=.000$ ). This concludes that the regression model used in this study is adequate or in other words, the model was fit.

\subsection{Effect of Demographic Factors toward Business Success of SMEs}

One-Way ANOVA was used to find out whether age, education level, working experience and duration of organization operated have any significant effect on business success in SMEs. This technique examined the variability of the observation within each group as well as the availability between the group means. Therefore, it was conducted to find out whether the various groups are different in respect of business success. The results of the analysis show that only one of the demographic factors which are duration of organization operated has significant effect toward business success of SMEs. Duncan statistics shows that SMEs that are operated longer period have been more successful in compare to those have been in operation in a shorter period. In addition to this independent sample t-test was used find out whether gender plays any significant role in business success and found out that gender does play any role in Business Success of SMEs in Bangladesh. 


\subsection{DISCUSSION}

The purpose of this study was to identify the factors affecting the business success in small and medium sized enterprises in Bangladesh. A major implication for the findings is that these findings will able to give better understanding for entrepreneurs and business owners in addressing the factors which will significantly affect the business success in SME. The study of the factors affecting business success of SMEs is critical in understanding the business continuity and growth hence help supporting economic development within a country. The results of this study can also be used as reference for anyone who is interested to start their own business which will provide insights into decision making in staring a business and also for any companies which are interested to continue to sustain and grow.

To achieve business success, many factors should be optimal simultaneously, since SMEs success is a multidimensional phenomenon. Both firm-internal and firm-external factors affect firm success. Entrepreneurs in successful SMEs and those in failed SMEs thought that pretty much the same factors are the most important for business success, and held the same views on the factors to be avoided in business. The research has looked into characteristic of SMEs, management and know-how, products and services, the way of doing business and cooperation, resources and finance, and external environment.

The results show that products and services played an important role in ensuring the SMEs business success in Bangladesh. Innovative product, quality, cost, reliability, and services are the key strategic dimension in business success. Innovative product gives added value to the customer and it is important to achieve a suitable balance between product quality and costs. Small-business owners must have a missionary zeal about their products or services, be willing to be personally involved in it, be willing to stick with the business, be able to define the market clearly and pay attention to details and pro-activeness. Beside that, companies must compete based on their strength and specialization which is classified as cost leadership, differentiation, and focus (Michael Porter, 1985). Cost leadership-based companies have tight controls on their operational costs, have efficient production, are volume producers or focused on tonnage. Differentiation described companies which offer differences in their product or services. They tend to put brands as a market capture, have high service levels, unique distribution and non-standard terms of business. Lastly, focused companies are companies concentrating on a particular buyer, group, geographic area or segment of the product line. Continual improvement in quality, cost, delivery lead time, customer service and flexibility are part of the package to become world class. Innovators with continuous growth should pay special attention to their research and development, and the ability to maintain their innovativeness.

External environment factors play a very important role as well for firm success. Social network, government support, and legality, are the key strategic dimensions in external environment for business success. Networks represent a means for entrepreneurs to reduce risks and transaction costs and also to improve access to business ideas, knowledge and capital. A social network consists of a series of formal and informal ties between the central actor and other actors in a circle of acquaintances and represents channels through which entrepreneurs get access to the necessary resources for business

start-up, growth and success (Kristiansen, 2003). In developing areas, satisfactory government support has been shown to be important for small firm success (Yusuf 1995). In many cases, 
dealing with legal aspects has forced the SMEs to allocate significant amount of financial resources due to bribery practices. Legal aspect is often also used in selection operating decision in order to ensure future business success (Mazzarol \& Choo, 2003).

Business success is usually the outcome of the way of doing business and cooperation. Interfirm cooperation, consultation, performance measurement, and flexibility may play an important role in business success. Inter-firm cooperation contributes positively to gaining organizational legitimacy and to developing a desirable marketplace reputation. Cooperation also may enable the small firm to improve its strategic position, focus on its core business, enter international markets, reduce transaction costs, learn new skills, and cope positively with rapid technological changes. Successful firms were likely to spend more time communicating with partners, customers, suppliers, and employees. Use of outside professionals and advisors, and the advice and information provided by customers and suppliers is also important for business success. Networking seems to be important both between and within firms. The proportion of SMEs led by an entrepreneurial team was high among successful SMEs and low among failed SMEs, so fostering the formation of entrepreneurial teams in starting up businesses is recommended

A huge proportion of successful SMEs are led by men. However, there seems to be no association between the gender of an entrepreneur and SME success. Also, SMEs led by women are rarely growth seeking. From this point of view, it could be expected that women have underutilized growth potential. On one hand, women should be encouraged to become entrepreneurs, and on the other hand female entrepreneurs should be encouraged to expand their firms. However age of firm has a significant effect on the business success in SMEs; the longer the organization operates the more successful they are.

Early review indicates that SMEs play a vital role in the nation's economy and wellbeing. The largest concentration of SMEs, in terms of numbers, can be found in the textile and apparel sector, followed by food and beverages, and metals and metal products. Despite these governmental programs SMEs still face many challenges, domestic and external, which could hinder their resilience and competitiveness. They include: i) Ongoing difficulties in obtaining funds from financial institutions and the government. Usually the interest charges by financial institutions on loans borrowed by SMEs are high, and this is compounded by a lack of financial transparency by SMEs, ii) A lack of human capital is the most significant challenge facing SMEs. It is often too expensive for SMEs to employ a professional and competent workforce, iii) A high level of bureaucracy in government agencies hinders efficient SME business development operations, iv) A low level of research and development expenditure and v) A substantial orientation towards the domestic rather than international market place.

Having identified some of the challenges facing SMEs in Bangladesh, some strategies are recommended that the government, and its agencies responsible for SMEs (such as BSCIC among many others), and SMEs themselves may adopt. The government should play a leading role in educating SME practitioners on the incentives available to them and how to access them. These incentives should be delivered through an establishment that really cares for the success and sustainability of SMEs in the country.

Delivering government incentives through many channels, including profit making 
businesses such as commercial banks, creates confusion among SMEs and opens up the opportunity of a third party (for example a consultant or agent) to gain undue advantage by acting as a mediator between SMEs and the government. This makes access to such incentives cumbersome and expensive for small businesses. The government, therefore, should avoid delivering incentives through too many agencies (especially for-profit making ones), and also dismantle the bureaucratic procedures that cause inefficiency in government initiatives and projects. The government should increase the number of centers that offer consultancy and expert services to SMEs, and engage more experts in different areas (for example IT, financial planning, marketing planning etc). It should ensure that SMEs get these incentives at a lower cost and in a more effective way. The efficiency and effectiveness of the delivery system of incentives are vital to their utilization.

Regarding poor access to finance, the government should allocate more funds and delivered it through its agencies. There are numerous complaints by SMEs regarding the tough qualification criteria for accessing these funds and the bureaucracy in SME related agencies. Besides difficulties in meeting the requirement for these funds, SMEs also have difficulties because of transparency issues. On the other hand, SMEs in Bangladesh should not totally rely on government agencies; they should attempt to find their own path of progress by relying on strategies which allow them to access new markets, increase their revenue and expand their customer base. SMEs should always invest in market research, R\&D, and innovation in order to increase their competitiveness. By embarking on market intelligence they will be better able to understand the needs and wants in the marketplace. Such an understanding will assist in delivering superior value to customers compared to their competitors. This in turn will increase customer retention rates.

Third, "Small is beautiful" the saying goes. SMEs should therefore leverage the advantages of being small by deploying the relationship marketing strategy. The relatively small customer base of SMEs makes them more suitable for long-term customer relationships. By establishing long-term relationships with customers they are able to build customer loyalty and in turn reduce the cost of operation. Lastly, another strategy SMEs should consider is counter-trade. Counter-trade, or reciprocal trade, can assist SMEs in overcoming capital shortages, especially when they contemplate going overseas. A counter-trade strategy can also be used to access closed foreign markets besides allowing for transfer of technology and technological know-how from advanced countries to SMEs in developing nations like Bangladesh.

\subsection{CONCLUSION}

We attempted to find out the most significant factors that affect the Business Success of SMEs in Bangladesh and found out that product and services, external environment, and management know-how are the most significant determinants of Business Success of SMEs in Bangladesh. Products and Services hypothesis accepted as innovative and high quality of product gives added value to SMEs customer in Bangladesh. Most of the Bangladesh SMEs adopted Porter's Generic Strategies by Michael Porter; they are cost leadership, differentiation, and focus. To ensure Bangladeshi SMEs can continue to be successful they need to ensure good products and services delivered to customer continuously. External Environment hypothesis accepted as social network help entrepreneurs in Bangladesh to reduce risks and transaction 
costs, improve access to business ideas, knowledge and capital. Government support is vital to foster SMEs development and legal aspect is used in selection operating decision in order to ensure SMEs future business success. Hence, Bangladeshi SMEs should ensure they have built a strong social network and good government relationship in order to ensure their business success. The way of doing business and cooperation hypothesis accepted as inter-firm cooperation contributes positively to gaining organizational legitimacy and to developing a desirable marketplace reputation, and enables the small firm to improve its strategic position, focus on its core business, enter international markets, reduce transaction costs, learn new skills, and cope positively with rapid technological changes. Besides that, use of outside professionals and advisors should continue to be practiced by Bangladeshi SMEs. It is suggested that future researchers should increase the sample size and explore into agro-based SMEs.

\section{REFERENCES}

Asian Development Bank (ADB), Bangladesh, Strategic Issues and Potential Response-Small and Medium Enterprise Development and Export Expansion, Dhaka, 2002.

Asian Development Bank (ADB), "High Level Workshop on Strategic Issues and Potential Response Initiatives in the Finance, Industry and Trade Sector", November, 2001, Dhaka.

ADB (2001a), "Best Practice in Creating a Conducive Environment for SME" Policy Discussion Paper No. 1, Prepared by GFA Management and Swisscontact services under the ADB SME Development TA for Indonesia.

ADB (2001b), "Best Practice in Providing BDS to SMEs", Policy Discussion Paper No.2, Prepared by GFA Management and Swisscontact services under the ADB SME Development TA for Indonesia.

ADB (2001c), "Improving the Regulatory Framework for SMEs: Streamlining Business Formalization Procedures and Facilitating One-Stop-Services" Policy Discussion Paper No. 7, Prepared by GFA Management and Swisscontact services under the ADB SME Development TA for Indonesia.

Ahmed, M. U. 2003. The Economics of Small-scale Industries Revisited. Dhaka.

Ahmed, M. U. (2001), "Globalization and Competitiveness of Bangladesh's Small Scale Industries (SSIs): An Analysis of the Prospects and Challenges", Chapter 7 in Rehman Sobhan (ed.)Bangladesh Facing the Challenges of Globalization: A Review of Bangladesh's Development 2001, Centre for Policy Dialogue and University Press Limited, Dhaka.

Ahmed, M. U. (2000), "Development Potentials of Microenterprise in Bangladesh: An analysis of Issues and Constrants," Bangladesh Journal of Political Economy, Vol. 15, No. 1, pp 141-174.

Ahmed, M.U, "Development of Small-scale Industries in Bangladesh in the New Millennium: Challenges and Opportunities", Asian Affairs, Vol. 21, No.1, Jan-March, 1999. 
Ahmed, M.U, et.al. Small and Medium-Scale Enterprises in Industrial Development, Academic Publishers, Dhaka, 1992.

Arinaitwe, S. K. 2006. Journal of American Academy of Business, Cambridge, Hollywood, Vol. 8, Issue 2, pp. 167-178.

Audretsch, David B. 1990. The Economic Role of Small and Medium-sized Enterprises: The United States. Paper prepared for the June 11-12, World Bank Workshop on Small and Medium Enterprises.

Baker, W. \& H. Addams \& B. Davis (1993). Business planning in successful small firms. Long Range Planning 26 (6), 82-88.

Berry, A. 1997. SME competitiveness: The power of networking and subcontracting. Washington D.C. No. IFM-105.

Berry, Albert, and Dipak Mazumdar 1991. Small-scale Industry in East and Southeast Asia: A Review of the Literature and Issues. Asian Pacific Economic

Bhattacharya, D. (2002), "Bangladesh Economy in Fiscal Year 2001: Macroeconomic Performance", in Rehman Sobhan (ed.) Chapter 2 in Bangladesh Facing the Challenges of Globalization: A Review of Bangladesh's Development 2001, Centre for Policy Dialogue and University Press Limited, Dhaka.

Bracker, J. \& J. Pearson (1986). Planning and financial performance of small, mature firms. Strategic Management Journal 7 (6), 503-522.

Bridge, S., O’Neill, K. \& Cromie, S. 2003. Understanding Enterprise, Entrepreneurshipand Small Business. 2nd edition. New York. Palgrave Macmillan. ISBN 0-333-98465-X.

Foley, P. \& H. Green (eds.) (1989). Small business success. London: Chapman.

Gadenne, D. (1998). Critical success factors for small business: an inter-industry comparison. International Small Business Journal 17 (1), 36-56.

Ghosh, B. \& W. Kwan (1996). An analysis of key success factors of SMEs: a comparative study of Singapore/Malaysia and Australia/New Zealand, in The 41st ICSB World Conference Proceedings I, 215-252. Stockholm, Sweden, June 16-19.

Hallberg, K. (2002), “A Market Oriented Strategy for Small and Medium-Scale Enterprises" IFC Discussion Paper No. 40, The World Bank, Washington, D.C. Jobs Opportunities and Business Support (JOBs) Program, Growth potentials of Small and Medium Enterprises: A Review of Eight Sub-Sectors in Bangladesh, A Report prepared by Dr. Zaid Bakht, BIDS, for JOBS Sub-sector Study, 1998.

Henriette Hesselmann, Comcare, Peter Bangs. 2002. Benchmarking national and regional ebusiness policies for SMEs: Final report of the "E-business Policy Group". 
Hitt, M. \& D. Ireland (2000). The intersection of entrepreneurship and strategic management research, in Handbook of entrepreneurship, D. Sexton \& H. Landström (eds.), pp 45-63. Oxford: Blackwell.

Huggins, R. (2000). The success and failure of policy-implanted inter-firm network initiatives: motivations, processes and structure. Entrepreneurship and Regional Development, 12(2), pp 211-236.

Jarillo, J. (1988). On strategic networks. Strategic Management Journal 9 (1), pp 31-41.

Kauranen, I. (1996). The start-up characteristics of a new entrepreneurial firm as determinants of the future success of the firms in the short term and in the long term. Journal of Enterprising Culture 4 (4), pp 363-383.

Kristiansen, S. (2003). Linkages and Rural Non-Farm Employment Creation: Changing Challenges and Policies in Indonesia. Rome.

Kristiansen, S., \& Indarti, N. (2004). Entrepreneurial Intention among Indonesian and Norwegian Students. Journal of Enterprising Culture, 12(1).

Kristiansen, S., Furuholt, B., \& Wahid, F. (2003). Internet cafe entrepreneurs: pioneers in information dissemination in Indonesia. The International Journal of Entrepreneurship and Innovation, 4(4), pp 251-263.

Mazzarol, T., \& Choo, S. (2003). A study of the factors influencing the operating location decisions of small firms. Property Management, 21(2), pp 190-208.

Mazzarol, T., Volery, T., Doss, N., \& Thein, V. (1999). Factors influencing small business start-ups. International Journal of Entrepreneurial Behavior and Research, 5(2), pp 48-63.

McMahon, R. G. P. (2001). Growth and performance of manufacturing SMEs: The influence of financial management characteristics. International Small Business Journal, 19(3), pp 10-28.

Michael Porter (1985). Competitive Strategy, Techniques for Analyzing Industries and Competitors, Free Press, New York.

Morisette, S. and Mike Schraeder. 2007. Affirming entrepreneurship: the best hope for organizations. Development and Learning in Organizations

Nurul Indarti \& Marja Langenberg, (2005). A Study of Factors Affecting Business Success Among SMEs: Empirical Evidences from Indonesia.

Pelham, A. (2000). Market orientation and other potential influences on performance in small and medium-sized manufacturing firms. Journal of Small Business Management 38 (1), pp 48-67. 
Rana, A., Khan, J., Asad, A. and Mian, S. A. 2003. The SME Pulse: An exploratory Study of the Performance of SME'S in Pakistan and the Characteristics.

Salminen, A. (2000). Implementing Organizational and Operational Change - Critical Success Factors of Change Management. Helsinki University of Technology. Acta Polytechnica Skandinavica. Industrial Management and Business Administration Series No. 7. ISBN 951-666-540-3.

South Asia Enterprise Development Facility (SEDF/World Bank), The SME Sector: Taking Stock of the Present Situation, mimeo, Dhaka, 2003.

Storey, D. J. 2000. Understanding the Small Business Sector. London. Thomson Learning. ISBN 1-86152-381-5.

Swierczek, F. W., \& Ha, T. T. (2003). Entrepreneurial orientation, uncertainty avoidance and firm performance: an analysis of Thai and Vietnamese SMEs. International Journal of Entrepreneurship and Innovation, 4(1), pp 46-58.

UNECE (2003), Conclusions and Recommendations of the Expert Meeting on How To Become Suppliers of Large Enterprises and Transnational Corporations, held in Geneva on pp 20-21 March, 2003.

USAID, Bangladesh Enterprise Development Assessment Report, Vol. 1, 2001

Urata, Shujiro, and Hiroki Kawai 1998. Technological Progress by Small and Medium Enterprises in Japan. Paper prepared for the June 11-12, World Bank Workshop on Small and Medium Enterprises.

Westhead, P. (1995). Survival and employment growth contrasts between types of ownermanaged high technology firms. Entrepreneurship Theory \& Practice 20 (1), pp 5-28.

Wijewardena, H. \& S. Cooray (1996). Factors contributing to the growth of small manufacturing firms: perceptions on Japanese owner/managers. Journal of Enterprising Culture 4 (4), pp 351-361.

Wiklund, J. \& Shepherd, D. 2004. Entrepreneurial Orientation and Small Business Performance: A Configurational Approach. Journal of Business Venturing, Vol. 20. No. 1: pp 71-91.

William G, James M, Susan. (2005). Fundamentals of Business: Starting a Small Business. McGraw-Hill/Irwin: New York.

Yusuf, A. (1995). Critical success factors for small business: perceptions of South Pacific entrepreneurs. Journal of Small Business Management 33 (2), pp 68-73. 